\title{
Pengaruh Pengungkapan \\ Corporate Social Responsibility \\ terhadap Nilai Perusahaan dengan \\ Profitabilitas sebagai Variabel Pemoderasi
}

\author{
Muh Hosen Bawafi, Adi Prasetyo \\ Universitas Muhammadiyah Malang \\ Email: adiprasetyo@umm.ac.id
}

\begin{abstract}
$A B S T R A C T$
The purpose of this research is to examine the effect of Corporate Social Responsibility (CSR) disclosure on corporate value with profitability as a moderating variable. The research method that used in this research is quantitative and using analysis tool that is called SPSS. The result of this research is profitability variable as moderating variable proved empirically influence significantly correlation Corporate Social Responsibility and company value. In other words profitability can strengthen the influence of Corporate Social Responsibility to the value of the company at the time of high profitability of the company, and otherwise profitability can reduce the value of the company at the time of low profitability of the company.
\end{abstract}

Keywords: CSR, Disclosure, Profitability, Value's Company.

\section{PENDAHULUAN}

Dunia usaha pada saat ini tidak hanya semata-mata memperhatikan dari aspek keuangan perusahaan, melainkan juga aspek sosial, dan aspek lingkungan yang biasa disebut Triple Bottom Line. Sinergi tiga elemen ini merupakan kunci dari konsep pembangunan berkelanjutan (Siregar, 2007). Oleh karena itu, perusahaan tidak hanya berlomba untuk memenangkan kompetisi pasar dengan meningkatkan penjualan setinggi dan sebanyak mungkin untuk mencapai tingkat profitabilitas yang ditargetkan, tetapi perusahaan juga harus memperhatikan aspek lingkungan yang juga merupakan salah satu indikator keberhasilan perusahaan namun selama ini cenderung untuk dilupakan.

Ketika perusahaan berusaha untuk meningkatkan profitabilitas melalui penjualan atau produksinya, maka tingkat kesenjangan sosial dan kerusakan lingkungan juga semakin tinggi. Selain pihak yang terkait langsung dengan perusahaan, masyarakat dan lingkungan sekitar perusahaan juga merasakan dampak yang ditimbulkan oleh aktivitas operasi perusahaan. Oleh sebab itu, tanggungjawab perusahaan tidak hanya kepada para para investor dan kreditor dalam memenuhi kewajiban deviden ataupun memenuhi liabilitasnya, tetapi perusahaan juga berkepentingan untuk melihat lingkungan perusahaan dan memperhatikan kesejahteraan masyarakat disekitar perusahaan.

Setiap perusahaan pasti tidak terlepas dari masyarakat dan lingkungan sekitarnya, karena perusahaan dan lingkungan sekitar menciptakan hubungan timbal balik yang seharusnya bisa saling menguntungkan. Perusahaan membutuhkan suatu respon yang positif dari masyarakat yang dapat diperoleh melalui apa yang dilakukan oleh perusahaan kepada masyarakat. CSR adalah gagasan yang membuat perusahaan tidak hanya bertanggungjawab dalam hal keuangannya saja, tetapi juga terhadap masalah sosial dan lingkungan sekitar perusahaan agar per-

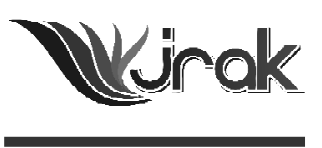

Jurnal Reviu Akuntansi dan Keuangan

ISSN: 2088-0685

Vol.5 No. 1, April 2015 Pp 721-730 
Pengaruh Pengungkapan...

722 usahaan dapat terus berjalan tanpa ada protes atau masalah yang timbul karena kurang memperhatikan lingkungan.

Gray, dkk. (1988) mengatakan bahwa manajer perusahaan akan mengungkapkan informasi sosial dalam rangka untuk meningkatkan nilai perusahaan, meskipun ia harus mengorbankan sumber daya untuk aktivitas tersebut. Dengan demikian, pengungkapan informasi tentang kepedulian perusahaan terhadap lingkunagan juga harus dilakukan oleh perusahaan karena secara tidak langsung hal tersebut akan menjadi pertimbangan investor atau kreditor terhadap kredibilitas perusahaan. Semakin baik tingkat pengungkapan CSR perusahaan dan didukung dengan baiknya tingkat profitabilitas, maka semakin baik pula nilai perusahaan tersebut.

Di Indonesia, penelitian tentang CSR telah pernah dilakukan, salah satu penelitian yang sudah dilakukan yaitu penelitian tentang pengaruh CSR dengan nilai perusahaan oleh Rosiana, dkk. (2013) yang berkesimpulan bahwa CSR berpengaruh positif dan signifikan terhadap nilai perusahaan manufaktur dan profitabilitas yang diperoleh atau dihasilkan perusahaan juga menjadi salah satu faktor yang mampu memperkuat pengaruh pengungkapan CSR terhadap nilai perusahaan. Muid (2011) melakukan penelitian dengan menguji pengaruh Corporate Social Responsibility (CSR) terhadap Stock Return dalam lingkungan perusahaan yang dikategorikan sensitif. Hasil penelitian ini menunjukkan hanya variabel CSR (social) secara parsial berpengaruh positif terhadap Stock Return, sedangkan variable CSR (environment) tidak berpengaruh terhadap Stock $R e^{-}$ turn. Secara bersama - sama dengan menggunakan variable control baik variabel environment dan social berpengaruh positif terhadap Stock Return. Hasil penelitian Nurjanah dkk. (2013) menunjukkan bahwa Aktivitas Corporate Social Responsibility menjadi salah satu upaya yang dilakukan untuk meningkatkan citra perusahaan di mata publik. Tanggung jawab sosial perusahaan atau CSR yang dilakukan terbukti mendapat sambutan positif dari masyarakat lokal.

Penelitian ini dilakukan untuk mengungkap seberapa besar peran pengungkapan Corporate Social Responsibility yang dilakukan perusahaan untuk meningkatkan nilai perusahaan dalam upaya meningkatkan profitabilitas, menarik investor dan kreditur untuk menanamkan modal dan berinvestasi pada perusahaan. Penelitian ini diharapkan dapat memperkuat penelitian-penelitian terdahulu dengan memilih perusahaan manufaktur yang berada langsung di sekitar atau berdekatan dengan tempat tinggal masyarakat sebagai objek penelitian karena perusahaan manufaktur cenderung besar untuk melakukan kontak langsung dengan lingkungan sekitar dan masyarakat. Penelitian ini mengacu pada penelitian Rosiana dkk. (2013) yang meneliti tentang pengaruh Corporate Social Responsibility terhadap nilai perusahaan dengan profitabitas sebagai variabel moderasi. Hasil penelitiannya menunjukkan bahwa CSR berpengaruh positif dan signifikan terhadap nilai perusahaan manufaktur, dan profitabilitas yang diperoleh perusahaan juga menjadi salah satu faktor yang mampu memperkuat pengaruh pengungkapan CSR terhadap nilai perusahaan, dan penelitian Dwijayanti dkk (2012) yang memperoleh kesimpulan bahwa pengungkapan CSR tidak terbukti berpengaruh pada hubungan kinerja keuangan dan return saham. Sehingga penelitian ini bertujuan untuk menguji kembali apakah Corporate Social Responsibility mempengaruhi nilai perusahaan dan profitabilas sebagai salah satu faktor yang memperkuat pengaruh pengungkapan CSR terhadap nilai perusahaan. Adapun hipotesis yang disusun dalam penelitian ini yaitu:

$\mathrm{H}_{1}$ : Pengungkapan Corporate Social Responsibility (CSR) berpengaruh positif terhadap nilai perusahaan.

$\mathrm{H}_{2}$ : Pengungkapan Corporate Social Responsibility (CSR) berpengaruh positif terhadap nilai perusahaan dengan profitabilitas sebagai variabel moderasi. 
Penelitian ini termasuk ke dalam jenis penelitian survey dan mengambil seluruh perusahaan manufaktur yang terdaftar di BEI sebagai populasi. Teknik sampling yang digunakan adalah purposive sampling, dengan kriteria sebagai berikut: (1) Perusahaan-perusahaan di Indonesia yang telah terdaftar di Bursa Efek Indonesia (BEI) tahun 2012-2014, (2) Perusahaan-perusahaan yang menerbitkan laporan keuangan tahun 2012-2014 dalam satuan mata uang rupiah, (3) Mengungkapkan informasi sosial dan informasi lainnya yang dibutuhkan selama tahun 2012-2014, (4) Memiliki data yang lengkap terkait dengan variabel-variabel yang digunakan dalam penelitian.

Teknik perolehan data pada penelitian ini untuk mendapatkan data sekunder adalah dokumentasi. Data sekunder tersebut ialah berupa laporan keuangan tahunan perusahaan yang di dapat melalui website BEI. Teknik analisis data yang disusun oleh peneliti terdiri dari beberapa tahap, yaitu: (1) menghitung jumlah pengungkapan CSR berdasarkan GRI (Global Reporting Initiative), (2) menghitung nilai perusahaan, (3) menghitung nilai profitabilitas, (4) melakukan analisis statistic deskriptif, (5) melakukan uji normalitas dan asumsi klasik, (6) melakukan uji hipotesis menggunakan analisis regresi.

\section{HASIL DAN PEMBAHASAN}

Objek penelitian yang digunakan dalam penelitian ini adalah perusahaan manufaktur yang terdaftar di Bursa Efek Indonesia, karena perusahaanperusahaan manufaktur lebih banyak mempunyai pengaruh atau dampak terhadap lingkungan sekitar sebagai akibat dari aktivitas yang dilakukan perusahaan. Penelitian ini menggunakan periode penelitian tahun 2012- 2014. Pemilihan sampel dalam penelitian ini ditentukan dengan menggunakan metode purposive sampling dengan beberapa ketentuan. Pengambilan sampel penelitian ini digambarkan pada tabel 1.

Pada tabel 2 dapat disimpulkan bahwa pada tahun 2012, perusahaan dengan index CSR tertinggi adalah PT. Kalbe Farma Tbk dengan nilai 0.358024691, nilai ini didapat dari jumlah pengungkapan CSR PT. Kalbe Farma Tbk sebanyak 29. Pada tahun 2013, perusahaan dengan index CSR tertinggi adalah PT. Indofood Sukses Makmur Tbk dengan nilai 0.345679012, nilai ini didapat dari jumlah pengungkapan CSR PT. Indofood Sukses Makmur Tbk sebanyak 28. Pada tahun 2014, perusahaan dengan index CSR tertinggi adalah PT. Indofood Sukses Makmur Tbk dengan nilai 0.382716049, nilai ini didapat dari jumlah pengungkapan CSR PT. Indofood Sukses Makmur Tbk sebanyak 31.

Tingginya jumlah item pada aspek lingkungan dan sosial ini dikarenakan kedua aspek tersebut sangat erat hubungannya dengan masyarakat, misal bila lingkungan sekitar perusahaan tercemar maka otomatis akan ada protes kepada perusahaan yang langsung atau tidak langsung akan berdampak negatif pada stabilitas perusahaan. Selain itu aspek sosial juga tinggi dikarenakan pada aspek ini juga sangat erat hubungannya dengan masyarakat, misal dengan program pengobatan gratis, selain bisa melaksanakan kewajiban dari undang-undang nomor 40 tahun 2007, perusahaan juga mendapat bonus citra yang baik di masyarakat. Hal tersebut tidak dapat dipungkiri bisa menjadi 
Pengaruh

Pengungkapan...

724

Tabel 1

Kriteria Sampel Penelitian

\begin{tabular}{clc}
\hline No & \multicolumn{1}{c}{ Kriteria } & Jumlah Perusahaan \\
\hline 1 & $\begin{array}{l}\text { Perusahaan-perusahaan manufaktur di Indonesia yang } \\
\text { telah terdaftar di Bursa Efek Indonesia (BEI) tahun } \\
2012-2014\end{array}$ & 37 \\
2 & $\begin{array}{l}\text { Perusahaan-perusahaan yang tidak menerbitkan } \\
\text { laporan keuangan tahun 2012-2014 dalam satuan mata } \\
\text { uang rupiah }\end{array}$ \\
3 & $\begin{array}{l}\text { Tidak mengungkapkan informasi sosial dan informasi } \\
\text { lainnya yang dibutuhkan selama tahun 2012-2014 }\end{array}$ \\
4 & $\begin{array}{l}\text { Tidak memiliki data yang lengkap terkait dengan } \\
\text { variabel-variabel yang digunakan dalam penelitian }\end{array}$ \\
& Total Perusahaan Sampel Penelitian \\
& Total Perusahaaan Sampel Penelitian Selama 3 Tahun
\end{tabular}

Sumber : Data Sekunder yang diolah, 2015

Salah satu faktor yang dapat meningkatkan laba perusahaan, karena konsumen cenderung memilih produk dari perusahaan yang memiliki citra baik. Di sisi lain, aspek ekonomi yang jumlahnya selalu sedikit atau bahkan tidak ada sama sekali dikarenakan pada aspek ini terlalu banyak persyaratan dan tidak begitu dirasakan oleh masyarakat. Salah satu contoh program dari aspek ekonomi adalah pemberian pinjaman modal untuk usaha kecil, selain hanya beberapa saja yang bisa mendapat pinjaman, program ini juga hanya bisa didapat apabila semua persyaratan sudah dipenuhi oleh calon penerima pinjaman. Hal tersebut yang membuat perusahaan cenderung memilih aspek lingkungan dan sosial dibandingkan dengan aspek yang lain.

Pada konteks nilai perusahaan, hasil ouput SPSS menunjukkan bahwa perusahaan dengan Tobin's Q tertinggi adalah PT. Unilever Indonesia Tbk dengan nilai 13.94263663.

\begin{tabular}{rlrrr}
\hline \multirow{2}{*}{ No Nama Perusahaan } & \multicolumn{3}{c}{ Index CSR } \\
\cline { 3 - 5 } & & \multicolumn{1}{c}{2011} & \multicolumn{1}{c}{2012} & \multicolumn{1}{c}{2013} \\
\hline 1 & PT. Akasha Wira International Tbk & 0.061728395 & 0.160493827 & 0.049382716 \\
2 & PT. Delta Djakarta Tbk & 0.037037037 & 0.172839506 & 0.135802469 \\
3 & PT. Gudang Garam Tbk & 0.098765432 & 0.12345679 & 0.111111111 \\
4 & PT. HM Sampoerna Tbk & 0.222222222 & 0.209876543 & 0.197530864 \\
5 & PT. Indofood Sukses Makmur Tbk & 0.271604938 & 0.345679012 & 0.382716049 \\
6 & PT. Kimia Farma TBK & 0.234567901 & 0.24691358 & 0.222222222 \\
7 & PT. Kalbe Farma Tbk & 0.358024691 & 0.308641975 & 0.345679012 \\
8 & PT. Martina Berto TBK & 0.222222222 & 0.135802469 & 0.12345679 \\
9 & PT. Multi Bintang Indonesia Tbk & 0.074074074 & 0.111111111 & 0.197530864 \\
10 & PT. Mayora Indah Tbk & 0.061728395 & 0.061728395 & 0.12345679 \\
11 & PT. Prasidha Aneka Niaga Tbk & 0.086419753 & 0.074074074 & 0.086419753 \\
12 & PT. Nippon Indosari Corporindo Tbk & 0.086419753 & 0.098765432 & 0.111111111 \\
13 & PT. Sekar Bumi Tbk & 0.061728395 & 0.111111111 & 0.098765432 \\
14 & PT. Mandom Indonesia Tbk & 0.12345679 & 0.12345679 & 0.135802469 \\
15 & PT. Tempo Scan Pacifik Tbk & 0.061728395 & 0.160493827 & 0.074074074 \\
16 & PT. Unilever Indonesia Tbk & 0.234567901 & 0.135802469 & 0.135802469 \\
\hline
\end{tabular}

Sumber : Data Sekunder yang diolah, 2015 
Pada tahun 2013, perusahaan dengan nilai Tobin's Q tertinggi adalah PT. Unilever Indonesia Tbk dengan nilai 16.28062028. Pada tahun 2014, perusahaan dengan nilai Tobin's Q tertinggi adalah PT. Unilever Indonesia Tbk dengan nilai 17.93508858. Sedangkan pada sisi profitabilitas, pada tahun 2012, perusahaan dengan nilai profitabilitas tertinggi adalah PT. Unilever Indonesia Tbk dengan nilai 0.539591156. Pada tahun 2013, perusahaan dengan nilai profitabilitas tertinggi adalah PT. Delta Djakarta Tbk dengan nilai 51.48014071. Pada tahun 2014, perusahaan dengan nilai Tobin's Q tertinggi adalah PT. Delta Djakarta Tbk dengan nilai 43.36379564.

Pengujian deskriptif statistik yang tersaji pada tabel menunjukkan nilai perusahaan yang diukur dengan Tobins $Q$. Rasio ini merupakan konsep yang berharga karena menunjukkan estimasi pasar keuangan saat ini tentang nilai hasil pengembalian dari setiap dolar investasi inkremental. Dari analisis deskriptif diketahui nilai rata-rata Tobins Q sebesar 4.872 atau 487.2\% dengan nilai standar deviasi 4.636. Nilai Tobins Q berkisar dari nilai terendah sebesar 0.613 (61.3\%) yaitu perusahaan PT. Martina Berto TBK pada tahun 2014 sampai dengan nilai tertinggi sebesar 17.935 (1793.5\%) yaitu perusahaan PT. Unilever Indonesia Tbk pada tahun 2014. Nilai rata-rata Tobins Q menunjukkan bahwa efektifitas manajemen perusahaan penelitian dalam memanfaatkan sumber-sumber daya ekonomi sebesar 4.872 atau $487.2 \%$.

Corporate Social Responsibility perusahaan manufaktur 2012-2014 yang diukur dengan membandingkan jumlah pengungkapan CSR dengan referensi silang dengan GRI G3.1 dan suplemen sektor manufaktur serta diberi kode CSRI. Hai ini menujukkan seberapa luas pengungkapan CSR pada perusahaan manufaktur yang menjadi objek penelitian. Hasil output statistik diketahui nilai rata-rata $\mathrm{Cor}^{-}$ porate Social Responsibility oleh perusahaan yang diamati sebesar 0.166 dengan nilai standar deviasi 0.089. Nilai CSR berkisar dari nilai terendah sebesar 0.058 yaitu perusahaan PT. Delta Djakarta Tbk pada tahun 2012 sampai dengan nilai tertinggi sebesar 0.358 yaitu perusahaan PT. Indofood Sukses Makmur Tbk pada tahun 2014. Nilai rata-rata CSR menunjukkan bahwa luas pengungkapan yang dilakukan perusahaan sebesar 0.166 .

Nilai rata-rata profitabilitas yang ukur dengan ROA yaitu membagi laba bersih setelah pajak dengan total aktiva. Tingkat profitabilitas yang semakin besar menunjukkan perusahaan mampu mendapatkan laba yang semakin besar, sehingga perusahaan mampu untuk meningkatkan aktivitas tanggung jawab sosial, serta mengungkapkan tanggung jawab sosialnya dalam laporan tahunan dengan lebih luas. Hasil output statistik diketahui nilai rata-rata profitabilitas oleh perusahaan yang diamati sebesar 2.184 dengan nilai standar deviasi 9.571. Nilai profitabilitas berkisar dari nilai terendah sebesar -0.047 yaitu perusahaan PT. Prasidha Aneka Niaga Tbk pada tahun 2014 sampai dengan nilai tertinggi sebesar 51.480 yaitu perusahaan PT. Delta Djakarta Tbk pada tahun 2013. Nilai ratarata profitabilitas menunjukkan bahwa besarnya pengembalian laba perusahaan kepada investor yang dilakukan perusahaan sebesar 0.179 .

\section{Uji Normalitas}

Alat yang digunakan untuk mendeteksi normalitas dalam penelitian ini adalah skewness- kurtosis dengan nilai kritis $\pm 2,58$ untuk alpha 0.01 . Selanjutnya nilai $\mathrm{Z}$ hitung skewness-kurtosis test dibandingkan dengan nilai kritis signifikan 0.01 yaitu \pm 2.58 . Jika nilai $Z$ hitung berada diantara nilai kritis maka model regresi berdistribusi secara normal Ghozali, (2006). Berdasarkan hasil perbandingan antara nilai $\mathrm{Z}$ hitung dan nilai signifikansi, dimana nilai $\mathrm{Z}$ hitung untuk ketiga variabel, yaitu Corporate Sosial Responsibility, profitabilitas dan nilai perusahaan (Tobin's Q) berada diantara nilai kritis \pm 2.58 (signifikansi 0.01). Sehingga dapat disimpulkan bahwa ketiga variabel berdistribusi secara normal. 


\section{Pengaruh Pengungkapan...}

\section{6}

Tabel 3

Hasil Koefisien Determinas

Tabel 4

Hasil Uji Simultan

\section{Pengujian Hipotesis}

Hasil perhitungan regresi moderasi antara Corporate Social Responsibility terhadap nilai perusahaan dengan profitabilitas sebagai moderator. Persamaan regresi yang terbentuk yaitu:

$\mathrm{Y}=-0.425+29.837 * \mathrm{X}+0.383 * \mathrm{XM}+\mathrm{e}$

Dari persamaan regresi dapat dijelaskan bahwa: (a) Koefisien konstanta (â $=-0.425$ ) menunjukkan bahwa tanpa adanya pengaruh dari Corporate Social Responsibility maka nilai perusahaan sebesar -0.425 satuan, (b) Koefisien regresi antara corporate social responsibility terhadap nilai perusahaan $(\beta=29.837)$ menunjukkan bahwa setiap 1 satuan nilai corporate social responsibility akan meningkatkan nilai perusahaan sebesar 29.837 satuan, (c) Koefisien regresi antara corporate social responsibility terhadap nilai perusahaan dengan moderasi profitabilitas $(\beta=0.383)$ menunjukkan bahwa setiap 1 satuan nilai Corporate Social Responsibility dengan moderasi profitabilitas akan meningkatkan nilai perusahaan sebesar 0.383 satuan.

Pengujian hipotesis dilakukan dengan koefisien determinasi, uji simultan, dan uji parsial. Koefisien determinasi (R2) dimaksudkan untuk mengetahui tingkat ketepatan paling baik dalam analisis regresi, dimana hal yang ditunjukkan oleh besarnya koefisien determinasi (R2) antara 0 (nol) dan 1 (satu). Selain itu, koefisien determinasi (R2) dipergunakan untuk mengetahui presentase perubahan variabel terikat $(\mathrm{Y})$ yang disebabkan oleh variabel bebas $(\mathrm{X})$.

Koefisien determinasi antara Corporate Social Responsibility dengan moderasi profitabilitas terhadap nilai perusahaan didapatkan nilai koefisien determinasi sebesar 0.531 yang artinya bahwa perubahan terhadap nilai perusahaan disebabkan oleh nilai perusahaan sebesar 53.1\%, sedangkan perubahan terhadap nilai perusahaan disebabkan oleh faktor lain di luar model sebesar 46.9\%. Selanjutnya, peneliti melakukan uji simultan. Uji simultan digunakan untuk menguji ada tidaknya pengaruh dari seluruh vari abel bebas terhadap variabel terikat dengan menggunakan uji statistik $\mathrm{F}$, di mana nilai $\mathrm{F}$ hitung yang lebih besar dari nilai $\mathrm{F}$ tabel atau $p$-value yang lebih kecil dari á $5 \%$ menunjukkan adanya pengaruh simultan. Uji simultan antara Corporate Social Responsibility dengan moderasi profitabilitas terhadap nilai perusahaan didapatkan nilai $\mathrm{F}$ hitung (25.435) lebih besar dari nilai $\mathrm{F}$ tabel (3.204) atau $p$-value (0.000) lebih kecil dari alpha 5\% (0.050) menunjukkan bahwa terdapat pengaruh signifikan antara Corporate Social Responsibility dengan moderasi profitabilitas terhadap nilai perusahaan.

\begin{tabular}{ccc}
\hline Variabel & $\mathbf{R}$ & $\mathbf{R}^{2}$ \\
\hline Corporate Social Responsibility + Moderasi Profitabilitas & 0.728 & 0.531 \\
\hline
\end{tabular}

Sumber: Data Diolah, 2015

\begin{tabular}{lccc}
\hline Variabel & F-hitung & p-value & Keterangan \\
\hline $\begin{array}{l}\text { Corporate Social Responsibility } \\
\text { + Moderasi Profitabilitas }\end{array}$ & 25.435 & 0.000 & Signifikan
\end{tabular}

Sumber: Data Diolah, 2015

Uji parsial digunakan untuk menguji ada tidaknya pengaruh dari tiap variabel bebas terhadap variabel terikat dengan menggunakan uji statistik t, di

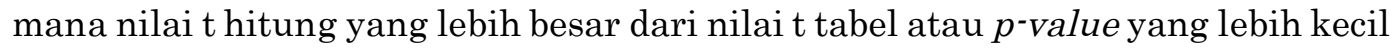
dari $\alpha 5 \%$ menunjukkan adanya pengaruh parsial. Uji parsial antara Corporate Social Responsibility terhadap nilai perusahaan didapatkan nilai t hitung (5.033) lebih besar dari nilai t tabel (2.014) atau $p$-value (0.000) lebih kecil dari alpha 5\% (0.050) menunjukkan bahwa terdapat pengaruh signifikan antara Corporate So- 
cial Responsibility terhadap nilai perusahaan. Uji parsial antara Corporate Social Responsibility dengan moderasi profitabilitas terhadap nilai perusahaan didapatkan nilai t hitung (2.297) lebih besar dari nilai t tabel (2.014) atau p-value (0.026) lebih kecil dari alpha 5\% (0.050) menunjukkan bahwa terdapat pengaruh signifikan antara Corporate Social Responsibility dengan moderasi profitabilitas terhadap nilai perusahaan.

\begin{tabular}{lccc}
\hline \multicolumn{1}{c}{ Variabel } & t-hitung & p-value & Keterangan \\
\hline Corporate Social Responsibility & 5.033 & 0.000 & Signifikan \\
Corporate Social Responsibility & 2.297 & 0.026 & Signifikan \\
+ Moderasi Profitabilitas & & &
\end{tabular}

Sumber: Data Diolah, 2015

\section{Pengaruh Corporate Social Responsibility Terhadap NilaiPerusahaan}

Berdasarkan output SPSS versi 21, hasil penelitian menunjukkan bahwa variabel Corporate Social Responsibility berpengaruh signifikan terhadap nilai perusahaan. Hasil penelitian ini menunjukkan bahwa besar kecilnya praktik Corporate Social Responsibility mempengaruhi peningkatan nilai perusahaan. Hal ini sesuai dengan teori bahwa perusahaan bukanlah entitas yang hanya beroperasi untuk kepentingan sendiri namun harus memberikan manfaat bagi stakeholdernya.

Tujuan utama perusahaan adalah meningkatkan nilai perusahaan. Nilai perusahaan akan terjamin tumbuh secara berkelanjutan (sustainable) apabila perusahaan memperhatikan dimensi ekonomi, sosial, dan lingkungan. Adanya praktik CSR yang baik, diharapkan akan memberikan citra yang baik pada pihak eksternal. Hasil dari penelitian ini mendukung penelitian tentang pengaruh Corporate Social Responsibility dengan nilai perusahaan oleh Gunawan dan Utami (2008) yang menggunakan sampel perusahaaan yang terdaftar di BEI pada tahun 20052006 dan memperoleh kesimpulan bahwa CSR berpengaruh positif terhadap nilai perusahaan yang apabila semakin banyak perusahaan dalam mengungkapkan item pengungkapan sosialnya dan semakin bagus pengungkapannya maka akan semakin tinggi dampaknya terhadap nilai perusahaaan.

\section{Pengaruh Profitabilitas sebagai Variabel Moderating dalam Hubungan antara Corporate Social Responsibility dan Nilai Perusahaan}

Hasil penelitian ini menunjukkan bahwa variabel profitabilitas sebagai variabel moderasi dapat mempengaruhi hubungan Corporate Social Responsibility dan nilai perusahaan. Dengan kata lain, profitabilitas dapat memperkuat pengaruh Corporate Social Responsibility terhadap nilai perusahaan pada saat profitabilitas perusahaan tinggi, dan sebaliknya, profitabilitas dapat menurunkan nilai perusahaan pada saat profitabilitas perusahaan rendah. Berpengaruhnya profitabilitas di dalam hubungan antara Corporate Social Responsibility dan nilai perusahaan antara lain disebabkan oleh banyaknya perusahaan manufaktur di tahun 2012-2014 yang telah melaksanakan program CSR dan terbukti hal tersebut mampu meningkatkan dan hasil penelitian menunjukkan sebesar apapun tingkat Corporate Social Responsibility perusahaan dapat mempengaruhi hubungan antara CSR dan nilai perusahaan. Hasil penelitian ini mendukung hasil penelitian Rosiana dkk. (2013) memperoleh kesimpulan bahwa Corporate Social Responsibility berpengaruh positif dan signifikan terhadap nilai perusahaan manufaktur dan profitabilitas yang diperoleh atau dihasilkan perusahaan juga menjadi salah satu faktor yang mampu memperkuat pengaruh pengungkapan CSR terhadap nilai perusahaan. 


\section{Pengaruh Pengungkapan...}

728

\section{SIMPULAN}

Tujuan penelitian ini adalah untuk menguji pengaruh variabel Corporate Social Responsibility dengan profitabilitas sebagai variabel moderasi terhadap nilai perusahaan (firm value) yang diproksikan dengan Tobin's Q. berdasarkan analisis dan pembahasan menggunakan alat uji regresi linear berganda yang dilakukan dalam penelitian ini dengan menguji 16 sampel perusahaan manufaktur selama 3 tahun. Hasil penelitian ini berkesimpulan bahwa (1) Corporate social responsibility terbukti secara empiris berpengaruh signifikan terhadap nilai perusahaan. Hal ini menunjukkan semakin luas dan semakin tingginya tingkat pengungkapan Corporate Social Responsibility maka semakin tinggi pula nilai perusahaan secara keseluruhan dilihat oleh pasar. (2) Variabel profitabilitas sebagai variabel moderating terbukti secara empiris mempengaruhi secara signifikan hubungan Corporate Social Responsibility dan nilai perusahaan. Dengan kata lain profitabilitas dapat memperkuat pengaruh Corporate Social Responsibility terhadap nilai perusahaan pada saat profitabilitas perusahaan tinggi, dan sebaliknya profitabilitas dapat menurunkan nilai perusahaan pada saat profitabilitas perusahaan rendah.

Penelitian ini mempunyai keterbatasan-keterbatasan yang dapat dijadikan bahan pertimbangan bagi peneliti berikutnya agar mendapatkan hasil yang lebih baik lagi. Penelitian ini hanya menggunakan Corporate Social Responsibility (CSR) sebagai variabel bebas dalam pengaruhnya terhadap nilai perusahaan. Selain itu, perusahaan yang menjadi sampel penelitian hanya dari perusahaan manufaktur yang berjumlah 16 perusahaan dengan tahun pengamatan pada tahun 20122014. Keterbatasan terakhir yaitu subyektif dalam menilai luas pengungkapan. Hal ini terjadi karena setiap pembaca melihat pengungkapan pertanggungjawaban sosial yang diungkapkan perusahaan dari sudut pandang yang berbeda-beda.

Berdasarkan keterbatasan pada penelitian ini, adapun saran-saran yang dapat diberikan melalui hasil penelitian ini agar mendapatkan hasil yang lebih baik, yaitu: (1) Penelitian selanjutnya diharapkan menggunakan penerapan Good Corporate Governance (GCG) selain Corporate Social Responsibility (CSR) sebagai variabel bebas dalam pengaruhnya terhadap nilai perusahaan. (2) Penelitian selanjutnya menggunakan variabel lain sebagai variabel moderating hubungan Corporate Social Responsibility dan nilai perusahaan, misalnya: leverage, size perusahaan, dll. (3) Penelitian selanjutnya diharapkan menggunakan seluruh perusahaan dengan sampel yang lebih banyak dan tahun pengamatan yang lebih lama. (4) Penelitian selanjutnya diharapkan melibatkan pihak lain dalam menentukan luas pengungkapan sebagai bahan pemeriksaan kembali.

\section{DAFTAR PUSTAKA}

Dwijayanti. N.M.A., M.G. Wirakusuma dan I. Suardikha. 2012. Pengaruh Tingkat Pengungkapan CSR pada Hubungan Antara Kinerja Keuangan dan Return Saham. E-Jurnal Ekonomi dan Bisnis Universitas Udayana, Vol. 1, No. 01, hlm: 1-14.

Gray, R., D. Owen dan K. Maunders. Corporate Social Reporting: Emerging Trends in Accountability and Social Contract. Accounting, Auditing \& Accountability Journal, 1(1), 6-20

Ghozali. 2006. Analisis Multivariate dengan Program SPSS. Edisi Ke 4. Badan Penerbit Universitas Diponegoro. Semarang.

Gunawan, B. dan S.S. Utami. 2008. Peranan Corporate Social Responsibility Dalam Nilai Perusahaan. Jurnal Akuntansi dan Keuangan, Vol. 7, No. 2, hlm: 174-185.

Muid, D. 2011. Pengaruh Corporate Social Responsibility Terhadap Stock Return. Fokus Ekonomi, Vol. 6, No. 1, hlm: 105-121. 
Nurjanah, N.E., Salam dan R. Awza. 2013. Pengelolaan Corporate Social Responsibility (CSR)Dalam Membangun Citra Perusahaan. Jurnal Ilmu Komunikasi, Vol. 2, No. 2, hlm: 1-82.

Republik Indonesia. 2007. "Undang-undang No. 40 tentang Perseroan Terbatas". Ikatan Akuntansi Indonesia. Jakarta.

Rosiana, G.A.M.E., G. Juliarsa dan M.M.R. Sari. 2013. Pengaruh Pengungkapan Csr Terhadap Nilai Perusahaan Dengan Profitabilitas Sebagai Variabel Pemoderasi. Jurnal Akuntansi Universitas Udayana Vol. 5, No. 3, hlm: 723738.

Siregar, C.N. 2007. Analisis Sosiologis terhadap Implementasi Corporate Social Responsibility pada Masyarakat Indonesia. Jurnal Sosioteknologi, Vol. 6, No. 12, hlm: 285-288. 
